\title{
Research on the Leap Forward Development of Nujiang Autonomous Prefecture in Yunnan Province China- Also on the Development of Minorities Regions in Southwest China
}

\author{
Luo Weiyou \\ Ideology and Politics Dept., Chuxiong Normal University, Chuxiong, Yunnan Province, China \\ Email address: \\ 1wy@cxtc.edu.cn
}

\section{To cite this article:}

Luo Weiyou. Research on the Leap Forward Development of Nujiang Autonomous Prefecture in Yunnan Province China- Also on the Development of Minorities Regions in Southwest China. Earth Sciences. Vol. 4, No. 6, 2015, pp. 252-260. doi: 10.11648/j.earth.20150406.16

\begin{abstract}
Nujiang Lisu Autonomous Prefecture Yunnan Province, China (hereinafter the Nujiang Autonomous Prefecture for short) set of frontier, ethnic religion, poverty, ecological and natural disasters in one, is a typical representative of the southwest frontier ethnic regions. Harsh geological and ecological environment and frequent natural disasters make the frontier ethnic masses in poverty and backwardness, backward and poverty and aggravate the ecological environment deterioration, this vicious cycle of long-term role, the formation of "Nujiang problem", has become a long-term control of the development bottleneck of Nujiang Autonomous Prefecture. In mountainous and towns from the perspective of the development of ecological migration, transforming the mode of production of the steep slope land reclamation, the elimination of bottlenecks in the development, "break a leap forward development path". The southwest frontier ethnic regions achieve 2020 completely solve poverty mission objectives, built southwest borderland "the construction of ecological civilization pacesetter, ethnic unity and progress of the demonstration zone" has practical significance.
\end{abstract}

Keywords: Frontier National Regions, Eco-migration, Overcome Poverty Become Rich, Leaping Development

\section{中国云南省怒江州跨越发展研究一一兼论中国西南边疆民族地区 发展}

\section{罗维有}

楚雄师范学院思政部, 楚雄, 云南, 中国

\section{邮箱}

1wy@cxtc. edu.cn

\begin{abstract}
摘要：中国云南省怒江傈僳族自治州（以下简称怒江州）集边疆、民族宗教、贫困、生态和自然灾害于一体，是西 南边疆民族地区的典型代表。恶劣的地理地质生态环境和频发的自然灾害使边疆民族群众陷于贫困与落后，落后与 贫困又加剧生态环境恶化，这种恶性循环圈长期作用，形成 “怒江问题”，成为长期制约怒江州发展瓶颈。在生态 移民山地城镇化发展视阈下，转变陡坡农垦生产方式，消除发展瓶颈，“闯出一条跨越式发展的路子来”。使西南 边疆民族地区实现2020年完全解决贫困任务目标，建成西南边疆 “生态文明建设的排头兵，民族团结进步示范区” 具有现实意义。
\end{abstract}

关键词：边疆民族地区，生态移民，脱贫致富，跨越发展 


\section{1. 引言}

云南省怒江州地处滇西北青藏高原南延横断山脉纵 谷地带, 辖沾水县、福贡县、贡山独龙族怒族自治县和兰 坪白族普米族自治县, 总国土面积14703平方公里, 共有 29 个乡（镇），260个行政村（办事处），总人口 53.4 万 人, 其中农业人口 41.6 万人, 占 $77.9 \%$ 。2012年末全州城 镇化率 $24.15 \%$ 。

贫困、地质环境条件恶劣和自然灾害是怒江州发展的 结症, 恶劣的地理地质生态环境和频发的自然灾害导致边 疆民族群众贫困, 贫困又加剧生态环境恶化。由此形成恶 性循环圈, 成为长期制约怒江州发展瓶颈。怒江州拥有富 集的自然生态资源, 开发利用富集的自然生态资源, 能够 有效破解长期制约怒江州发展瓶颈, 但受多种因素限制, 富集的自然生态资源一直得不到应有的开发利用, 发展瓶 颈长期得不到破解。在新常态下, 怒江州应从生态环境保 护恢复——民族群众脱贫致富——富集资源科学适度开 发利用等三个维度思谋解破发展瓶颈。从生态移民与加快 是山地镇化发展着手, 主动融入国家生态文明建设、面向 西南开放 “桥头堡” 、西南民族团结边疆稳定示范区, 新 一轮西部大开发、连片特困地区扶贫等战略, 探索出一条 适合怒江州转变生产发展方式的新路子, 推动怒江州跨越 式持续发展, 实现全面小康目标, 对加快西南边疆民族地 区同步实现全面小康目标具有现实紧迫性和借鉴意义。

\section{2. 怒江州是边境民族极端贫困与生态环境十分 脆弱相互交织}

怒江州不仅少数民族比重大，民族群众的贫困面广贫 困度深, 而且边境线长, 自然生态环境脆弱, 人口生存环 境恶劣, 但拥有富集的资源, 尤其是水资源和探险旅游资 源得天独厚。

\section{1. 怒江州边境线长, 少数民族比重大, 民族群众贫困 度极深}

怒江州地处滇缅印结合部, 南北最大纵距 320.4 公里, 东西最大横距153公里, 但国境长达449. 5公里, 占中缅边 境线的 $20 \%$, 占云南省边防线的十分之一。全州优各县, 其中有 3 个边境县, 2 个涉藏工作县, 有多个境外非政府组 织在境内活动, 多个境外电台用少数民族语言对内广播, 边境维稳压力大。怒江州是云南省会昆明到南亚直线距离 最短的地州, 泸水县片马口岸是中缅两国间最大的陆路贸 易口岸和滇西北通往东南亚的惟一陆路通道。多年来, 怒 江立足沿边片马口岸优势, 扩大对外开放带动全州发展, 为建设中国面向西南开放 “桥头堡” 重要新通道奠定了基 础。

怒江州主要居住着傈僳、白族、怒族、普米族、独龙 族等 12 个民族, 其中独龙族、怒族属于怒江独有的少民族, 少数民族人口占 $87.65 \%$, 是全国民族族别成份最多和全国 人口较少民族最多的自治州, 是全国唯一的僳傈族自治州。
主体民族傈僳族是云南省 4 个特困民族之一，90\%以上的怒 族、 $89 \%$ 以上的普米族群众处于贫困状态，白族支系 “拉 玛人”、“勒墨人”, 景颇族支系 “茶山人” 整体处于深 度贫困状态。怒江州至今还是云南乃至全国最贫困的少数 民族自治州, 全州所属 4 个县都是国家级贫困县, 全州 29 个乡镇有 21 列为贫困乡镇, 有 523 个深度贫困自然村, 181 个行政村列为扶贫开发重点村, 占行政村总数的 $70 \%$, 居 云南省之首。到2014年底, 按照最新的贫困标准 2300 元, 怒江农民人均纯收入低于 2300 元的贫困人口还有 22.97 万 人, 其中还有 785 元以下的 5.89 万深度贫困人口, 贫困发 生率达 $51.61 \%$ 以上，近70\%的农民生活在贫困线以下 ${ }^{1}$ 。怒 江州除了经济上的极度贫困之外, 社会发展进程极其缓慢 及其社会封闭状态更令人震惊。怒江州民委副主任李勇在 接受 “中国经济时报” 记者采访时说, 怒江州总体上是一 个从原始社会直接过渡到社会主义社会的少数民族自治 州, 社会发展进程仍处于社会主义初级阶段的最低层次, 是个集边疆、民族、山区、贫困、宗教五位一体的民族自 治州。

地理环境特殊, 自然灾害频繁, 生存发展环境恶劣, 民族群众只能靠陡坡垦殖、广种薄收的方式来满足基本生 存需要。怒江民族群众的贫困呈现出区域性和生存条件恶 化贫困的状态。

当全国大多数地方的人们都在共享着改革发展成果 奔向幸福小康社会时, 怒江仍严重缺路、缺水、缺电, 大 部分群众还没有享受到最基本的公共服务, 农村运输以人 背马驮和过溜索为主。至今还有 1284 个自然村未通公路。 水利化程度仅为 $31.8 \%$, 城镇化率仅为 $24.15 \%$, 是云南水 利化和城市化水平最低的州市。

\section{2. 怒江州自然生态资源富集}

怒江州蕴藏着世界级的矿产、水能和旅游资源, 集自 然地貌博物馆、人类文明处女地、民族文化大观园、生物 物种基因库和爱国主义陈列馆为一体, 既是 “三江并流” 世界自然遗产的重要组成部分, 又具有多姿多彩的民族文 化风情。

\subsection{1. 矿产资源蕴藏丰富多样}

境内已发现各类金属矿藏28种，矿床点294个，其中 小型以上矿床 27 处。主要金属矿有铅、锌、银、铜、铁、 锡、金、铇、采、钼、镍、锑等。铅锌是本州主要矿产, 有 30 多个矿床和矿点, 已探明铅锌储量 1664 万金属吨以上。 兰坪县金顶凤凰山铅锌矿床是中国已探明的最大铅锌矿 床，也是世界上特大铅锌矿床之一。

\subsection{2. 水能资源极为丰富}

境内江河纵横交错, 水域面积达 1.02 万公顷。118条 中小河流羽状排列注入怒江, 36条中小河流汇入澜沧江, 独龙江有 13 条支流。水能理论蕴藏量达 2000 万千瓦, 可开

(1) 怒江州怒江州政府扶贫开发办公室: 2014年怒江州扶贫开发工作总 结, 2015年2月。 
发的装机容量达 1800 万千瓦 (占云南省可开发量的 $19.9 \%$ ), 年发电量可达 850.9 亿千瓦时（占云南省的 $18.7 \%$ ）。

\subsection{3. 生物资源种类繁多}

已知的高等植物就有 200 多个科、680余属、3000多种, 国家级保护植物有 42 种（多为乔木树种）。已知中药材资 源356种，其中药用植物314种。全国76个药材资源重点保 护品种中怒江州境内就有 51 种。境内脊椎动物 488 种, 其 中鸟类138属、284种, 有32种为中日保护候鸟, 8 种为世 界濒危种类。

\subsection{4. 自然景观奇异独特}

高黎贡山、碧罗雪山、担当力卡山、云岭四山夹怒江、 澜沧江、金沙江相间排列, 形成一江拽两山、两山夹一江 的怒江大峡谷、澜沧江大峡谷和独龙江大峡谷等峡谷景观, 怒江大峡谷长 316 公里, 高低差5000多米, 拥有世界级的 养生资源, 是科考、探险绝佳神秘地。滇西北独有的 “三 江并流” 风景区, 景区内飞瀑悬天, 峡谷幽深, 林海苍茫, 江河奔江, 是世界自然遗产, 是人类自然文化宝藏。拥有 峡谷奇观 “石月亮”、怒江第一湾、天然地质剖面一一独 龙江绝壁、雄伟林立的冰斗雪峰、神秘的溶洞、云岭—— 兰坪罗锅等丹霞地貌、板块碰撞的地质景观和丰富的珍稀 植物, 是大范围、多功能的风景名胜区。怒江大峡谷, “三 江并流” 是中国 “香格里拉” 生态旅游的核心区, 云南正 在全力打造的滇西北世界级精品旅游品牌。

\subsection{5. 民族文化浓郁多彩}

怒江民族文化浓郁独特, 绚丽多彩, 是多宗教和谐共 存，多民族和谐发展的人类民族文化大观园。

\section{3. 怒江州生态环境在中国西南边疆的战略地位极为重 要, 但生态脆弱, 生态植被受损严重}

正如怒江州州长李四明所说: “生态是怒江最重要的 资源和资本, 是生存之基、发展之本。” “怒江生态区位 重要, 生物种类丰富, 生物区系关键, 战略地位特殊, 承 担着维护国家生态安全的重大责任, 保护好怒江的自然生 态环境, 着力推进 “森林云南”怒江建设, 对于维护云南 乃至国家的生态安全和生物多样性具有十分重要的现实 意义。” 素有 “动植物王国明珠” “世界物种基因库”之 称的怒江, 是世界十大生物多样性地区之一, 境内有世界 自然遗产 “三江并流” 4 个主要片区和自然保护区, 面积 达 898.95 万亩, 面积占全州国土面积的 $58.3 \%$, 其中仅高 黎贡山国家级自然保护区和云岭省级自然保护区总面积 就有 599.4 万亩, 占全州国土面积的 $27.2 \%$ 。怒江州是云南 省自然保护区面积最大和自然保护区占国土面积比例最 大的地州。

由于行政区划不合理, 怒江州境内群山䇯立, 江河纵 横, 行成 “四山夹三江” 的大峡谷地形地貌, 地势北高南 低, 平均谷深 2000 米, 海拔 4000 米以上的山峰多达 40 余座, 最高峰高黎贡山楚鹿腊卡峰海拔为 5128 米, 有长约 3 公里 的现代悬冰川、冰舌前缘下伸到海拔 4000 米处; 最低点为
海拔738米的沪水县境内的蛮云村怒江边。境内除兰坪县 的通甸镇、金顶镇, 泸水县的上江乡有少量较为平坦的山 间槽地和江河冲积滩地外，多为高山陡坡，全州 $99.7 \%$ 的 国土面积均为高山区, 可耕地面积极少, 垦殖系数不足 $4 \%$, 有效耕地面积仅为 75.29 万亩, 人均耕地不足 1.5 亩, 耕地 沿山坡垂直分布, $76.6 \%$ 的耕地坡度均在 25 度以上。可耕 地中高山地占 $28.9 \%$, 山区半山区地占 $63.5 \%$, 河谷地占 $7.6 \%$, 相当部分耕地被称为 “挂在墙壁上的大字报地” 山高、坡陡、谷深、自然灾害频繁是怒江的真实特点。水 土流失面积达3933平方公里、占全州国土面积的 $26.8 \%$, 地质灾害隐患点达 880 多处。有近 12 万贫困群众需要通过 移民安置搬出不宜生存地区。

由于坡度陡，当地的农耕种植有 “壁耕”之称，人们 形象地称其为 “大字报田”。曾有新华社记者说: “看怒 江人民种地就像看豚木鸟啄树”。原全国人大常委会副委 员长许嘉璐到怒江视察时曾说: “你们种的不是粮食, 你 们种的是灾难!”这是怒江人民生存无奈的表达。在怒江, 不仅 “壁耕” “刀耕” “火种” 极大地破坏生态环境, 而 且获取生存所需要的热能、修建民房等都在大量砍伐木材。 怒江水能资源极为丰富, 但民族群众没有电, 烧火做饭取 暖，只有砍树，现在甚至连树根都刨出来当柴烧。

近年来，滑坡、泥石流、山洪等自然灾害更有愈演愈 烈的趋势。据资料统计, 2004年, 怒江州共发生地质灾害 681 起, 其中以福贡县 “ 4.16 ” 和泸水县片马 “ 7.18 ” 两 起特大地质灾害最为严重, 共造成 22 人死亡, 9 人失踪, 35 人受伤, 直接经济损失 2.7 亿元。怒江的地质灾害大小 不论年年有, 每年泥石流、塌方等自然灾害给当地各族群 众造成了人民财产安全的巨大损失和威胁，仅 2010 年 “7.26” “8.18” 两次特大山洪泥石流自然灾害, 就造成 近百人死亡，直接经济损失上亿元。2014年 “ 5 ・ 10 ” 福 贡县上帕镇腊吐底泥石流灾害中, 由于成功预警, 村民 265 人全部撤离, 无人员伤亡，但 14 户村民无家可归，平均每 户的损失都超过 10 万元; “6 -30 ” 福贡县上帕镇腊吐底 村俄玛底木本尼发生大型滑坡地质灾害, 造成9人死亡、6 人失踪、 3 人受伤; “ $7 \cdot 9$ ” 福贡县匹河乡沙瓦河发生泥 石流灾害, 造成 17 人失踪、 1 人受伤。

2014年7月11日，怒江州地质灾害防治工作现场会在 福贡召开。州长李四明在会上指出, 我州是全省地质灾害 防治的重灾区, 怒江、澜沧江、独龙江三条大江共有一级 支流173条, 还有很多二级支流, 全州境内共有滑坡、泥 石流等地质灾害隐患点 883 处, 受威胁人口 10.8 万人, 受 威胁财产17. 27 亿元。从今年5月份以来, 全州四县 29 个乡 镇都不同程度遭受洪港、山体滑坡、泥石流等地质灾害, 受灾人口达6. 44 万人, 农作物受灾 4972 公顷、绝收 1209 公顷, 民房受损和倒塌2317间, 直接经济损失 1.25 亿元。 这些高度密集的地质灾害隐患点, 在降雨、地震和不当的 人为工程活动诱发下, 极易发生滑坡、泥石流、崩塌等地 质灾害。

这些频发的地质灾害惨痛现实警示着我们, 也促使我 们反思和寻找规避怒江地质灾害、保护和修复生态环境、 确保民族群众彻底脱贫致富奔小康的方法途径。 


\section{3. 怒江州发展取得新成效}

在恶劣地理环境、脆弱的生态环境条件下，尤其是近 年来, 在保护自然生态环境的约束和限制丰富多样的水资 源、生物资源、矿石资源开发利用的条件下，怒江州结合 自己的区位资源人文等州情实际, 抓住国家实施的“天保” 工程、“退耕还林还草”工程、扶贫工程和西南 “桥头堡” 面向东南亚对外开放战略、云南生态文明建设排头兵、西 南边疆稳定示范区战略机遇, 党的十八大精神指引下, 树 立尊重自然、顺应自然、保护自然的生态文明理念, 把生 态文明建设放在突出地位, 融入经济建设、政治建设、文 化建设、社会建设各方面和全过程, 努力建设 “美丽云 南・生态怒江”, 取得了前所未有的发展成效。

\section{1. 扶贫工程建设成效显著}

怒江州在扶贫工程建设中, 结合州情实际探索扶贫移 民新路子，开展扶贫工作，获得显著成效。

1996年开始, 怒江州通过跨地州移民安置、县内采取 小片区开发、山头搬山脚、移民建镇、插花安置等模式, 累计移民安置 8707 户 37289 人 (州扶贫办实施的安置人数 为 3963 户 17400 人、州发改委实施的安置为数为 4744 户 19889人），其中：跨州市安置3800人（1996年在省政府 的关心下, 怒江州泸水县和福贡县与普耳市场经济签订了 跨州市易地开发安置协议, 1996-1999年四年间先后普耳 市翠云区踏清河, 漫志江片区转移安置1800万人, 保山芒 宽安置 2000 人）、州内安置转移 33489 人。

表一 怒江州按年度实施扶贫移民安置情况表。

\begin{tabular}{|c|c|c|c|c|c|}
\hline 年份 & $\begin{array}{l}\text { 组织移民安 } \\
\text { 置单位 }\end{array}$ & $\begin{array}{l}\text { 移民安置 } \\
\text { 户数(户) }\end{array}$ & $\begin{array}{l}\text { 移民安置 } \\
\text { 人数 (人) }\end{array}$ & $\begin{array}{l}\text { 移民总投资 } \\
\text { (万元) }\end{array}$ & $\begin{array}{l}\text { 备 } \\
\text { 注 }\end{array}$ \\
\hline 1999 & 州扶贫办 & 931 & 4000 & 865 & \\
\hline 2000 & 州扶贫办 & 949 & 4000 & 760.72 & \\
\hline 2001 & $\begin{array}{l}\text { 州扶贫办、 } \\
\text { 州发改委 }\end{array}$ & 2296 & 9680 & 3928.7 & \\
\hline 2002 & $\begin{array}{l}\text { 州扶贫办、 } \\
\text { 州发改委 }\end{array}$ & 1196 & 5404 & 2827 & \\
\hline 2003 & $\begin{array}{l}\text { 州扶贫办、 } \\
\text { 州发改委 }\end{array}$ & 841 & 3439 & 1975 & \\
\hline 2004 & 州发改委 & 82 & 332 & 183 & \\
\hline 2005 & 州发改委 & 375 & 1600 & 717.7 & \\
\hline 2006 & $\begin{array}{l}\text { 州扶贫办、 } \\
\text { 州发改委 }\end{array}$ & 145 & 997 & 500 & \\
\hline 2007 & $\begin{array}{l}\text { 州扶贫办、 } \\
\text { 州发改委 }\end{array}$ & 780 & 3286 & 1642 & \\
\hline 2008 & $\begin{array}{l}\text { 州扶贫办、 } \\
\text { 州发改委 }\end{array}$ & 1112 & 4551 & 1428 & \\
\hline 合计 & & 8707 & 37289 & 14827.12 & \\
\hline
\end{tabular}

通过易地开发扶贫移民，全州10年共投入资金1.4827 亿元, 移民安置8707户 37289 人（见表一）。这些移民搬 迁农户基本实现了一年定居、二年增收、三年解决温饱的 目标。

十二五以来, 怒江州累计投入专项扶贫资金 8 亿多元， 发放信贷扶贫资金 3 亿多元，累计实施整村推进1255个, 实施整乡推进 8 个, 全州贫困人口从 2011 年的 31.29 万人,
减少到 2013 年的 22.96 万人，每年的减贫速度在 $15 \%$ 以上; 农民人均纯收入从 2005 年的 990 元，增加到 2013 年的 3251 元，贫困人口大幅度减少”。怒江州扶贫攻坚2013、2014 年度5大工程规划计划投资 166032.4 万元，实际到位资金 188107.08 万元，占国家和省级年度计划投入资金的 $113 \%$ 。 扶贫资金的及时超额到位，确保了5大工程各项目的顺利 启动实施。目前, 又争取落实各类扶贫资金44274.63万元, 其中: 财政专项扶贫资金33929.63万元，信贷扶贫到户规 模资金 10000 万元，项目管理经费 345 万元， 继续扶贫攻 坚。实践证明: 易地开发扶贫移民是解决怒江缺乏生存条 件贫困人口温饱, 脱贫致富奔小康的有效途径。

\section{2. 怒江州生态文明建设成果丰硕}

2000年以来, 怒江州累计投入生态保护建设资金超过 11 亿元, 通过实施重点生态保护建设工程, 怒江生态文明 建设取得了显著成绩。

从上世纪末，国家实施 “天然林保护、退耕还林、农 村能源、生物多样性保护” 为主的生态环境建设工程以来, 怒江州确立了 “生态立州” 的发展思路和 “以生态建设为 主” 的发展战略, 坚持走 “生态建设产业化、产业发展生 态化”的科学之路。

近年来, 怒江面对生态建设问题, 根据海拔不同, 生 态区域特色和人均环境特色, 确立了保护措施。施行规划 先行, 并将生态整体规划归结为 “纵横坐标图” , 即: 纵 向坐标则代表怒江建设生态立体保护体系, 横向坐标代表 与生态发展立体化的协调起步。立体坐标的拟定更加直观 地显现生态建设格局。具体措施是：纵向坐标 “封” “进” “移” “退” “预” “建” 即 “山顶封和禁、半山移和 退、河谷建和育” 的立体生态保护模式; 横向坐标 “四个 百万工程”，经济发展和生态保护齐头并进。

“封” 和 “进”，杜绝生态破坏一一对怒江山顶海拔 高达2000米以上, 生态环境保持良好状态。目前, 怒江出 台了最严厉的 “封山育林” 措施，禁止牧、耕、猎、伐等 活动, 严格保护原始自然生态景观; “移” 和 “退”, 实 现生态恢复——在海拔2000米至1500米之间的山体部分, 由于遭遇过破坏, 导致生态环境比较脆弱。面对生态脆弱 区, 以生态移民和退耕还林为重点, 积极实施移民退耕工 作, 截止到 2012 年, 实施生态移民4853户, 共计 21683 人, 退耕还林 35 万亩, 更有效的实现生态植被恢复; “育” 和 “建” , 加大生态保护——在1500米以下河谷地带, 土地 资源相对比较丰富, 气候炎热潮湿, 特殊的生存环境有助 于植被快速生长。

“四个百万工程” 即是: 实施 “百万亩林果基地” “百 万亩中草药种植基地” “一百万株庭院经济林基地” “一 百万头牲畜畜牧基地” 工程, 是怒江开启的 “混农林业” 发展模式, 该模式有助于林下经济增长。

怒江州以 “城镇面山绿化工程和身边增绿工程” 为载 体, 将每年6月第一周定为全州法定植树周, 组织绿化荒 山荒地活动, 从2010年到2012年, 累计营造林 300 余万亩、 义务植树 1200 万株。怒江森林面积由 1496 多万亩增加到

(1)怒江州政府扶贫开发办公室: 2014年怒江州扶贫开发工作总结, 2015 年2月。 
1609万亩，森林覆盖由 $68 \%$ 提高到 $72.96 \%$ ，森林蓄积量由 1.52 亿立方米增加到 1.66 亿立方米。全州森林覆盖率、森 林蓄积量、森林生态服务价值等重要指标均排在全省前列。 生物多样性保护成效凸显, 戴帽叶猴、滇金丝猴、羚羊等 国家重点保护野生动物种群不断扩大。滇金丝猴数量逐年 上升, 从 5 年前的 280 只增长到约 480 只, 占全国总数的 $28 \%$ 。

\section{3. 边境口岸建设初具规模}

怒江州泸水县片马镇是云南连接南亚、东南亚的自由 贸易的西北边陲重镇, 是怒江州沿边对外开放的边境口岸, 在州、县各级党委政府的共同努力下, 片马镇口岸建设取 得了新成就, 集小额贸易、林矿产品开发、替代种植于一 体的初级复合型沿边口岸小城镇基本形成, 田已经具备一 定的发展基础, 有很大的发展潜力, 片马镇口岸已成为怒 江对外开放的 “名片”，展示形象的 “窗口”，与外界沟 通交流的 “桥梁”。片马镇口岸的建设, 为云南怒江进 一步扩大对外开放的领域、提升对外开放的层次、提高对 外开放的效益、拓宽边境群众增收渠道奠定了基础。

\section{4 . 经济持续增长}

紧紧围绕强基础、强产业、强生态，保民生、保稳定、 保和谐的工作要求, 抓好各项工作的落实, 全面实现经济 社会发展目标，保持了经济发展、社会进步、文化繁荣、 民生改善、边疆安宁的良好局面。全州城镇居民人均可支 配收入由 2010 年的 10479 元增加到 2012 年的14221元, 年均 增长 $16.49 \%$ 。农村居民人均纯收入由 2010 年的 2005 元增加 到2012年的 2773 元, 年均增长 $17.6 \%$ 。2013年全年实现生 产总值 85.82 亿元，增长 $14.5 \%$; 规模以上固定资产投资 82.87 亿元, 增长 $30.2 \%$; 社会消费品零售总额 23.51 亿元, 增长 $13.9 \%$; 地方公共财政预算收入 8.41 亿元, 增长 $12.1 \%$; 单位生产总值能耗下降1.7\%。怒江州2013年比1953年（建 州前一年）国民生产总值增长822倍; 地方财政收入增长 1789 倍; 农民纯收入增长260倍。

2014年怒江州农村经济总收入 25,46 亿元，同比增长 $14,5 \%$; 农民年人均纯收入 3855 元，同比增长 $11.5 \%$ 。

\section{4. 制约怒江州跨越发展的瓶颈一直得不到破解}

怒江州长期以来受自然、地理、交通，边疆、历史等因 素的制约, 经济社会发展严重滞后, 民族群众的贫困面广, 贫困度极深; 民族群众为生存而掠夺破坏生态环境，使生态 环境越来越脆弱和恶化。民族群众贫困与生态环境恶劣相互 作用制约, 形成中国具有典型性和代表性的极为特殊的集边 疆、民族、生态、贫困交织为一体的 “怒江问题” 。

\section{1. 制约怒江州跨越发展瓶颈的形成}

首先, 地质地貌的陡峭奇险, 森林植被的茂盛, 孕育 了怒江极为丰富的生物资源、水资源、旅游资源和少数民

(1)段志涁，罗金合：怒江大峡谷网，2015. 1. 12

(2)段跃庆: 把怒江建设成为中国面向西南开放的 “桥头堡” 的重要新通 道，今日民族，2011.4
族文化资源; 其次, 地理地质环境条件的陡峭险峻恶劣、 生态环境的脆弱和耕地的极端稀缺, 极大地限制着怒江人 们的发展, 决定了民族群众的贫困; 第三, 恶劣的地理地 质环境条件和脆弱的生态环境条件下，个体、小群体和社 区的民族群众为生存而对这些丰富资源的改造利用, 效率 极其低下, 从稍长一点的历史时期看, 没有效率, 只会产 生更大的负效应, 破坏生态环境, 使生态环境更加脆弱, 地理地质环境更加恶劣, 给民族群众带来更大的灾难, 民 族群众陷入更深的贫困之中。生态环境恶劣——民族群众 贫困一一生态环境更恶化一一民族群众更贫困。这种恶性 循环，成为怒江州跨越发展的制约瓶颈。

\section{2. 破解制约怒江州发展瓶颈的初步探索}

怒江州虽然社会总体上处于落后, 民族群众贫困面广、 贫困度深, 但却拥有水和生态两大富集资源。结合怒江的 地理环境和富集资源, 怒江人们在积极探索怒江跨越发展 的途径。首先, 充分利用怒江极为丰富的水资源, 发展怒 江水电产业, 是怒江转变发展方式的直接有效途径, 既保 护生态环境, 又充分发挥水资源效益, 彻底解决民族群众 脱贫发展的保障问题。但又陷入堪比当年 “三峡工程” 的 激烈争论之中, 致使怒江水电开发长期搁置。正如怒江州 原州长解毅指出: “在怒江, 要变也不是不可能的, 因为 怒江人口少, 资源那么多, 又是后发展的, 关键的问题是 允不允许怒江人民选择符合于自己发展的道路。”

在怒江跨越发展的“第一条路”-—水电开发没有迈 出步伐的困境下, 怒江人们正在探索第二条跨越发展的 “生态兴州”之路。即实施异地开发、进行扶贫移民，把 一部分生活条件恶劣、人地矛盾突出和生活在生态脆弱区 的贫困人口在政府的组织协调下实行搬迁移民、异地安置, 把扶贫开发和生态建设进行有效结合、建立生态保护和经 济发展良性互动模式的重要途径。但制约怒江州跨越发展 的这种恶性循环瓶颈依然长期得不到破解。

\section{3. 难以有效破解怒江州跨越发展制约瓶颈的根源}

制约怒江州跨越发展的这种恶性循环瓶颈形成并长 期得不到破解, 从客观上说, 是行政区划极为不合理, 全州民族群众都被限制在高山峡谷沟壑之中, 生存发展 环境恶劣, 经济社会极为落后。而当前怒江人们又承担 着远远超过自己财政能力的生态环境保护任务, 一方面, 财政资金投入严重不足。另一方面，“就地取材”，开 发利用怒江自己拥有的富集资源, 又受到种种因素的限 制。引用怒江州官员之言：“在极端贫困状态下，我们 承担了大量的生态保护任务，全州50\%的国土面积是保 护区, 现在的状况是跟上时代的环境保护却远远落后于 时代的资源开发。”这决定着怒江州难以摆脱这种恶性 循环瓶颈实现跨越发展。但从主观上看, 一是民族自治 制度优越性发挥不够充分, 缺少适合怒江州实际需要的 制度政策支持，极大地限制着丰富资源的开发利用; 二 是基本局限于州内或县内乡镇小范围内思谋发展, 缺少 跳出县州小范围, 站在省、国家更高更大的范围谋划发 展战略思想; 三是与时俱进地把握跨越发展机遇, 及时 转变发展方式的力度不够; 四是对边疆这张牌没有打好, 
面向云南西北边境开放的重要窗口还没有充分发挥其应 有的作用。以至于 “怒江问题” 长期处于争论之中, 得 不到有效破题解决。

\section{5. 破解制约瓶颈, 推动怒江州跨越发展的对策与 建议}

“叠翠荫蔽蝉鸣闻, 镜湖映山花缤纷。落霞红云剪酌 影, 彩云之南修仙人。” 行于山水之间, 感受生态之美, 这是对云南省怒江州自然生态环境最真实的写照。怒江州 在发展瓶颈的制约下, 也有自己发展的后劲和优势。结合 怒江州边疆、民族、贫困、生态等的实际, 在深入分析认 识怒江州制约发展的瓶颈及其成因基础上, 对怒江州如何 实现跨越发展, 特提出以下对策建议:

\section{1. 怒江州需要在全省、全国的大格局中来研判思谋可 持续发展途径}

在新常态下, 面对新的形势、新的任务、新的机遇, 必须把怒江置于全国、全省的大格局中加以审视，站在更 高层次、更大范围正确判断面临的形势, 准确把握怒江在 生态文明建设、新一轮沿边开放新格局的机遇, 来思谋怒 江州跨越式的可持续发展。

首先，怒江的边疆、民族宗教、生态环境、多样性生 物资源、世界遗产 “三江并流 “、丰富的水矿石资源，特 有的旅游资源等度具有具有全省性、全国性, 有的还具有 国际性。理所当然, 怒江民族群众的贫困问题, 也具有全 省性、全国性, 只能在全省性、全国性层面来审视谋划, 才能得到彻底解决。

其次, 受行政区划造成的地理环境的限制, 怒江州的 富集资源开发利用, 尤其是水资源的开发利用是怒江州实 现跨越发展的直接有效路径, 但怒江不能自主开发利用富 集资源尤其是水资源, 就等于财源被切断, 失去生存基础, 失去实现小康目标的自主发展能力。这就需要在国家层面 来寻找新的发展途径, 才能使怒江民族群众不掉队, 跟随 全国人民一切实现小康目标。

第三，国家以省市、地州行政区域来划定耕地红线守 护的亩积数量的做法本身就极为荒谬。这种荒谬的行径, 一方面, 山区、生态功能区 $8^{\circ}$ 以上, 甚至 $25^{\circ}$ 以上陡峭 山坡地、“壁挂地” 被 “守护”（如云南怒江、昭通、汶 山等), 由此而来的是水土流失、水源枯竭, 破坏生态环 境, 自然灾害频发; 另一方面, 直接导致平原、坝子肥沃 高产的优质良田，被日益扩张的城市建筑、被爆发肆虐的 洪水、被过度的煤炭开采等吞噬。

极度令人费解的是平坝、平原的煤炭过度开采, 乱象 从生、严重污染环境, 破坏生态、灾害频发, 人们已经习 以为常; 怒江水电资源开发替代砍伐树木利用能源, 却被 百般指责成破坏生态环境、污染河流。

结论就是在国家、省区（市）层面来划定全国耕地保 护红线, 与全国生态功能区划定相匹配。宜保护生态环境 的区域坚守生态红线, 退耕还林还草, 实施生态移民; 宜 保护耕地良田的区域坚守耕地红线, 逼迫城镇化向山地延 伸, 建设山地城镇安置移民。怒江州就以保护生态环境为
主题, 及时彻底转变农耕发展方式为生态环保发展方式, 将 $25^{\circ}$ 以上的耕地农田退耕还林, $25^{\circ}$ 以下的耕地适度保 持本地菜蔬供给, 将怒江州去掉粮食生产功能。一方面, 靠生态纵横补偿; 另一方面, 科学适度开发水电资源、旅 游资源和矿、石资源, 发展西北边境口岸贸易, 建设环境 友好型怒江，走可持续发展之路。

第四, 从当前在生态环境和贫困以及富集资源自主开 发被限制等多重压力下, 怒江州委、州政府以生态文明建 设为主, 实施 “生态兴州” 战略, 扶贫移民、保护生态环 境、沿边口岸建设、经济社会发展等都取得显著的成效, 有目共睹。但从全州的长远发展来看, 由于没有从全省、 全国的高度层面来谋划协调怒江的发展, 而使怒江的发展 中缺少应有的财政资金和政策支持，由此，怒江目前发展 所取得的显著成效, 也就带有突出的短期性和不可持续性。 例如扶贫移民绝大部分移民都是从山头移到山脚, 在州内 就近安置, 既没有从根源上彻底解决原本脆弱的生态环境, 因民族群众为生存而造成生态环境持续恶化的问题; 也没 有彻底解决民族群众不依赖脆弱恶化的生态环境, 走上脱 贫致富道路的问题。在地理地质条件的限制下, 移民安置 点的水、电、路通讯、教育、卫生等公共设施的建设不仅 投入巨大, 享受的人口数少, 效率很低, 而且, 这些公共 设施, 还需要加倍的投入维修, 还难以保证正常投入使用。 如公路, 年年修建, 新挖的山体年年滑坡, 年年有民族群 众的生命财产受到严重损失。再如搬迁到怒江河谷的民族 移民群众必将在怒江水电资源开发中面临着二次移民搬 迁。从怒江州扶贫移民中，在省委、省政府的协调下，向 州外的安置的那一部分移民来看, 虽然移民过程中协调难 度大一些, 但鲜果就完全不同。

可见，只有在全省、全国的大格局下，从长期可持续 发展来规划怒江的生态移民, 移民才会有较好的产地的到 安置; 移民才能够有相应的财政资金保障, 走上致富道路; 生态环境才会得到真正的恢复保护。怒江州跨越持续发展 的制约瓶颈才能破解。

\section{2. 在全省、全国的大格局下, 从长期可持续发展来规 划, 实施生态移民, 建设发展山地城镇安置移民, 实现怒江州跨越式发展}

生态移民和山地城镇化都以人口的迁移, 实现相应的 规模集聚发展来完成。怒江州的生态环境恢复保护、民族 贫困群众的脱贫、水电资源的开发利用、沿边口岸建设等 都需要通过生态移民与山地城镇化建设发展途径来实现。

\subsection{1. 建立统一协调领导机构}

在全省层面成立集多部门为一体的云南省生态移民 与山地城镇建设办公室, 领导协调全省生态移民与移民安 置地的山地城镇建设。并把保护生态环境的移民、扶贫移 民、自然灾害移民、工程建设移民全部纳入生态移民范围 统一协调组织进行。

\section{2. 2. 将 “怒江州生态移民与山地城镇化发展” 提升为国 家层面的项目建设}

将怒江州生态移民与山地城镇化发展置于云南省生 态移民与山地城镇建设办公室领导协调下开展。一是从 
生态文明建设排头兵、面向南亚东南亚辐射中心、西南 边疆民族团结示范区、连片贫困民族地区扶贫、涉藏区 域建设、中国主要江河源头保护、生物多样性保护等层 面, 经过充分的调研论证基础上, 努力将 “怒江州生态 移民与山地城镇化发展” 提升为国家层面的项目建设, 确保相应的财政资金支持。作为国家项目或者省级项目 来实施怒江州生态移民与山地城镇化建设, 才能够确保 项目建设的财政资金支持。才能够确保怒江州生态移民 与山地城镇化建设的顺利实施, 获得可持续发展的多赢 成效。二是通过组织相关技术力量充分勘测规划论证基 础上, 科学选择合理布局生态移民迁入地, 整族、整乡 推进生态移民, 建设具有浓郁民族人文特色的山地小城 镇。既为进一步开发怒江州民族生态旅游资源奠定基础, 又能够避免进一步开发怒江水电资源进行二次移民。

\section{2.3. 建设山地城镇安置移民}

怒江州经过10多年的扶贫移民工程建设, 到2013年底 累计贫困人口 22.96 万人。只要建设几个民族特色的山地 小城镇就可以接纳生态移民的 20 几万人口迁入。具体的民 族特色山地小城镇建设, 可以在沾水县片马口岸基础上、 在卢库与保山之间开发民族经济旅游地带、可以在怒江、 澜沧江等河谷将来水电开发的水位线以外的地势低缓地 带、有进一步发展前景条件的原有乡镇附所在地, 勘探规 划建设民族特色山地小城镇。

\section{2. 4. 实施生态移民与山地城镇化建设, 实现多赢}

实施怒江州生态移民与山地城镇化建设的预期效益 极为硕大。对怒江州、云南省、全国, 以至东南亚等不 同层面都能够产生极大的外溢效应; 怒江州的民族贫困 问题、生态环境保护问题、生物多样性保护问题、世界 遗产 “三江并流” 保护问题、中国以至东南亚主要江河 源头保护问题、怒江水电开发利用问题、怒江一一香格 里拉国家级旅游开发问题等都能够以此而获得最大化的 收益。

需要的一个前提, 是国家或者云南省先预付实施怒 江州生态移民与山地城镇化建设的资金成本。实际上, 退一步说, 即使努力争取不到国家级的项目建设资金支 持, 只要能够作为省级项目, 在加大省财政资金支持下, 把目前投入到怒江州的扶贫、农村水电路等公共设施建 设、自然灾害治理、旧房改造等资金集中起来，也能够 有效推进实施怒江州生态移民与山地城镇化建设工程。

积极努力争取在 “十三・五” 期间, 基本完成怒江 州生态移民与山地城镇化建设工程, 破解怒汇州发展的 制约瓶颈, 实现怒江州跨越式发展, 跟全国一起实现全 面小康目标。一方面, 彻底解决了怒江州面临的民族群 众贫困和生态环境保护压力, 及时停止民族群众为生存 对生态环境的掠夺破坏, 使生态环境得到保护恢复; 又 使民族群众摆脱恶劣的生态环境的限制, 重新开辟发展 空间, 彻底脱贫致富。另一方面, 为怒江州、云南省和 国家科学合理地开发利用怒江的富集资源奠定基础。

\section{3. 实施生态移民, 建设发展山地城镇化安置移民, 实 现怒江州跨越式发展的几点建议}

\section{3. 1. 实施生态移民与山地城镇化建设, 破解怒江州发展 瓶颈}

借鉴邻省扶贫移民工程建设的案例, 结合当前把云 南建成民族团结示范区、生态文明建设排头兵、面向南 亚东南亚辐射中心新的目标定位, 根据习近平总书记关 于云南 “闯出一条跨越式发展的路子” 的要求。建议把 “生态移民与山地城镇化建设” 作为云南省 “十三 ・五” 规划的主要战略任务来实施, 成立 “云南省生态移民与 山地城镇化建设” 领导小组, 制定 “云南省生态移民与 山地城镇化建设实施办法” 指导组织实施云南省生态移 民与山地城镇化建设工程建设。把怒江州、昭通市、文 山州、迪庆州等连片贫困地区、生态保护区、生态环境 恶劣不适宜生存区等作为省级率先组织实施区域, 并积 极努力把具有全国典型性的怒江州申报为国家级的 “生 态移民与山地城镇化建设” 工程项目来建设。彻底破解 由贫困与生态相互交织而形成长期制约怒江发展的制约 瓶颈。

结合怒江州情，围绕生态环境保护恢复、现有陡坡 耕地保有量调整、民族（涉藏）扶贫、民族特色山地小 城镇建设、沿边口岸建设、公共基础设施建设、资源开 发治理等内容, 充分发挥民族区域自治权作用, 制定出 台新常态下 “怒江傈傈族自治州生态经济社会发展条例”, 使怒江州的生态经济社会在法治框架县依法依规开展。

一是以保护和恢复自然生态环境为怒江州长远发展目标, 大幅度调整现有耕地保有量, 将 $25^{\circ}$ 以上山坡耕地还林 还草, 切实转变发展方式, 狠抓生态文明建设。二是全 面实施生态移民，建设民族浓郁特色的山地小城镇，整 族整乡推进, 集中安置移民。三是科学规划资源的开发 利用, 依法排除怒江州生态经济社会发展中非政府组织 干扰破坏。四是清理和规范矿产资源探矿权、采矿权, 解决圈占资源、圈而不开、以探代采等问题, 加强对资 源开发科学管理和有效治理。

\section{3. 2. 加强怒江州沿边口岸山地城镇建设, 巩固云南西北 边境安全}

以沾水县片马镇口岸建设为依托, 加强云南西北边 境安全建设。对于具有戍守边防功能的边境居民, 由于 他们定居边境, 比派遣边防部队驻守边境, 从某种意义 上说, 守护边境安全的成效更高, 成本更低得多。建议 政府积极引导和帮助边境居民转变生产方式, 实行退耕 还林还草, 适度发展养殖业, 果林业替代种植业。使边 境居民更多在边境守护和生态环境看护方面发挥功能作 用, 戍守边境安全、保护边境生态环境。政府核准这部 分边境居民基数, 申请国家加大对这部分边境居民长期 定时定量补偿。用光伏电源、用电、用沼气池等替代这 部分边境居民的木柴生活生产能源。

\subsection{3. 着眼长远发展, 加强怒江州公共基础设施建设}

树立长远的发展观, 着眼于怒江州长远大发展, 科学 规划道路交通等公共基础设施建设, 杜绝基础实施建设的 
急功近利的政绩现象。将怒江州的现代交通运输 (高等级 公路、铁路、机场）的重大工程建设与怒江州 “生态移民 与山地城镇化建设”工程、富集资源开发利用、旅游探险 精品打造等统筹规划协调建设, 将怒江州的现代交通运输 基础实施建设立足于长期发展, 发挥综合效能最大化, 避 免时过近迁, 不适应怒江跨越发展需要, 又重建重修现代 交通运输施设。怒江州的地理地质环境条件下, 修建现代 交通运输施设, 远远比其他地州投入的成本大, 脆弱的生 态环境承受的压力更大。

\section{3. 4. 转变政绩考量方式}

建议用生态环境的保护与恢复成效 (全州森林覆盖率、 空气质量优良率达、地表水水质达标率、污水处理率、垃 圾处理率等逐年提高到一定的百分率）、绿色产业产值占 经济总量的比率、民族群众搬迁到适宜生存发展的山地小 城镇（脱贫致富, 才结和睦, 共同繁荣发展）、科学合理 开发水资源、旅游资源的成效等, 替代以经济指标 (GDP) 量化, 来综合考量怒江州的发展成效。

\section{3. 5. 以制度健全作保障支撑}

制定 “怒江傈傈族自治州生态移民搬迁与山地城镇化 发展实施管理条例”，使怒江州生态移民与山地城镇化发 展有相配套的移民条例和地方性法律、法规可循, 提高生 态移民的政策法规绩效，形成一定的约束力和强制性。条 例中应包括迁出地政府和迁入地政府的具体各项职责和补 偿规定。移民在迁入地的资源使用享受与原住民同等的权 利，对移民社区管理、对各种利益冲突和文化冲突相应的 控制防范措施以及冲突发生时有效的解决手段等。对跨地 州迁入地进行适度补偿, 以加强对迁入地的基础设施投入, 使移民和原住民共享道路、水利、电力、学校等基础设施, 促进地方经济发展。可以尝试把生态移民与怒江水电工程 移民相结合。按照迁入地接收移民的比例分享水电站建成 后用电环节的低价用电。

\section{3. 6. 强化少数民族文化的保护与传承, 增强移民适应性}

根据怒江州少数民族移民和独有少数民族移民的实 际情况, 把建设山地小城镇安置移民与少数民族文化的保 护传承进行有效结合。充分考虑怒江少数民族及少数民族 文化的可持续发展，充分保护民族文化特有的存在环境、 保护文化存在的人文环境。特别是涉及到怒江州的两个特 有民族: 独龙族、怒族的移民搬迁，应尽量不远离本民族 习惯居住范围。应尽量就民族、就信仰、就亲缘关系与地 缘关系来建设浓郁民族特色的山地小城镇安置, 使少数民 族移民城镇成为一个 “熟人城镇” , 探索民族文化与旅游 结合的发展之路。

\section{6. 结论}

\section{1. 生态移民与山地城镇化}

这里探讨的生态移民是指自然生态和生物多样性得到 有效保护, 使生态系统得以恢复和重建为重心的移民, 也 内在地包涵着当前局部实施的扶贫移民、自然灾害移民和
水利工程建设移民。因为这些移民的迁出而停止了对原居 住地生态环境的破坏，使生态环境得到修复和保护。

山地城镇化是指在高原山区丘陵地带现有城镇集镇集 市基础上, 通过科学规划和勘探以后, 向8-25度坡地、丘 陵扩建大、中、小城市、建制镇、小集镇、小集市来接纳 农村人口转移的过程。

生态移民与山地城镇化具有突出的共同点, 又有较大的 差异性。最根本的共同点在于二者都必须通过人口的迁移聚 居来完成, 人口的迁移都是从生存环境条件较差、较落后的 的农村地域转移到生活环境条件较好、具有现代公共设施服 务的区域。二者的目的意义都在于改善人们的生存生活的环 境条件, 共享文明成果, 促进经济社会生态政治文化协调发 展, 同步迈入小康社会。主要不同之处在于二者对人口原居 住地的外推力和新迁入地的吸附力不均衡。二者的对象虽然 都是农村人口为主, 但生态移民的对象是生存在生态环境脆 弱恶劣地区、生态功能区、自然灾害频繁区、工程建设征占 区的农村人口为主, 大型的国家工程建设和自然灾害涉及的 城镇人口也成为生态移民的对象。山地城镇化的对象则是具 有一定的经济实力, 又具有进城定居愿望的农村人口和山地 城镇化扩城建设征占了山地的失地农业人口。生态移民与山 地城镇化互为条件, 相辅相成, 相互作用, 相互促进, 二者 在经济政治文化社会生态全面协调可持续发展中, 各显特点, 从不同层面发挥着推动助力作用。

\section{2. 研究结论}

西南是中国少数民族聚居连片特困主要地区, 也是国 家划定生态保护红线的主要生态功能区, 是中国生态安全 的重要屏障。目前, 在全国14个连片特困地区中, 西南省

（市、区）涉及滇西边境片区、乌蒙山云南片区、迪庆藏 区和滇桂黔石漠化等多个片区, 这些连片特困地区不仅面 积大, 贫困人口多, 贫困度极深, 而且生态环境脆弱, 大 部分贫困人口生活在生态功能区和生态脆弱、自然条件恶 劣地区。贫困破坏该地区生态环境, 而生态环境遭受破坏 恶化又导致贫困不断加深, 形成中国西南边疆民族地区生 态环境与民族群众贫困恶性循环怪圈, 成为中国西南边疆 民族地区经济社会生态协调持续发展的瓶颈。

从生态移民与山地城镇化发展层面, 把实施生态移民 与推进山地城镇化相结合, 保护环境与民族群众脱贫致富 相结合, 守住生态红线与守住耕地红线相结合, 寻找破解 发展瓶颈的途径, 为全面贯彻落实习近平总书记考察西南 重要讲话精神, 推动西南边疆少数民族地区实现跨越式发 展，同步实现全面小康目标提供借鉴与参考。

通过对最具典型的中国西南边疆民族地区集民族（宗 教）、边疆、山区、贫困、生态为一体的云南省怒江州深 入调查研究, 结论认为: 破解中国西南边疆民族地区生态 保护区、生态脆弱地区自然生态环境和人口双重压力困境 的恶性循环怪圈, 实现生态环境得以保护修复、民族贫困 人口得以彻底脱贫致富、民族才结社会稳定边疆巩固的多 赢跨越发展, 有效途径就是推进实施中国西南边疆民族地 区生态移民工程建设, 加快山地城镇发展安置移民。

在地理环境条件制约下, 中国西南边疆民族地区城镇 的山地特征属性十分突出。但在不断加快发展的城镇化进 
程中, 城镇建设扩张背离山地不断吞噬相对平缓的平坝耕 地, 使平坝耕地良田在急剧消失, 城镇失去可持续发展的 基础。切实转变城镇建设发展向平坝延伸的趋向, 推进山 地城镇化发展成为中国西南边疆民族地区经济社会生态 协调持续发展的紧迫任务。

实施生态移民，使中国西南边疆民族地区的民族群众 离开十亩养不活一户人的 “壁挂地” ，彻底转变粗放的陡 坡农垦生产方式，摆脱恶劣生态环境的压迫，脱贫致富; 使中国西南边疆民族地区的自然生态环境得到修复和保 护。发展山地城镇优先安置生态移民, 坚守平坝耕地良田, 彻底改善自然生态环境和人口双重压力困境的恶性循环 怪圈, 破解发展瓶颈, 使中国西南边疆民族地区经济社会 生态协调持续发展。

\section{参考文献}

［1］段志彬，罗金合. 怒江大峡谷网，2015.1.12。
２］段跃庆. 把怒江建设成为中国面向西南开放的 “桥头堡” 的重要新通道 $[\mathrm{J}]$ 。 今日民族，2011.4。

[3] 张占斌: 将生态文明理念融入城镇化建设 [N]. 中国环境报, 2014. 1. 16。

［4］付保红, 杨品红, 李益敏. 怒江州农村特困人口现状及工程 移民扶贫研究 $[J]$ 。热带地理, 2007.9。

［5］冯芸, 陈幼芳. 云南怒江傈傈族自治州实施异地开发与生态 移民的障碍分析及对策研究 $[J]$. 经济问题探索, 2009. 3。

[6] 郑苗. 民族地区生态移民面临的问题及发展对策研究 [J]. 探索争鸣, 2013.7。

[7] 李纪恒. 认真学习贯彻党的十八精神, 积极探索有云南特色 的城镇化发展道路 [J]. 社会主义论坛, 2013.1。

[8] 侯晶晶. 探索生态文明建设的有效途径 [N]. 经济日报, 2014.1.21。

[9] 李媛媛, 李伟. 少数民族地区生态移民政策研究——以内蒙 古为例 $[\mathrm{M}]$. 经济科学出版社, 2015.5。 